\title{
Study on relationships between knowledge factors influencing Textile and Clothing disposal behaviour towards sustainable waste management
}

\author{
G Krishnaraj
}

Department of Textile Design, NIFT, Chennai, Tamil Nadu, India

To Cite this Article

G Krishnaraj, "Study on relationships between knowledge factors influencing Textile and Clothing disposal behaviour towards sustainable waste management", International Journal for Modern Trends in Science and Technology, 6(9S): 154-160, 2020.

\section{Article Info}

Received on 25-August-2020, Revised on 08-September-2020, Accepted on 12-September-2020, Published on 18-September-2020.

\section{ABSTRACT}

Increasing textile and clothing consumption resulted not only exhaustion of natural resources and virgin raw materials but also assimilation of textile material disposal from pre-consumer waste (i.e. various textile and clothing manufacturing activities) and post-consumer waste. Many environmental problems have been created by this pre-consumer and post-consumer waste generation. Adequate amount of measures has been taken by the government and standard organization to minimise the impact on environment by the textile manufacturing activities. Now a days, textile industries are striving to achieve zero waste generation by adopting various international standards and methods. But for the post-consumer waste generation issue, it is necessary for each and every consumer needs to understand and contribute for sustainable waste disposal. Hence, it is essential for everyone to know the existing sustainable concepts available to create sustainable environment. The main objective of the study is to examine the factors influencing textile and clothing disposal behaviour. The theory of disposal behaviour is related to consumer knowledge about textile product, environmental concern and waste management technique, namely Textile reuse and Textile recycle. Primary data was collected from 150 respondents through online questionnaires for this study. Statistical analysis such as correlation and regression were used with SPSS statistics. The research suggests that Apparel and Home textile product manufacturer should focus on creating consumer awareness on the possibility of reuse and recycle of the specific products along with the care label in order to achieve sustainable environment.

KEYWORDS: Textile and clothing Disposal behaviour, Environmental Concern, Consumer textile product knowledge, Textile reuse, Textile recycle.

\section{INTRODUCTION}

The growing population and modernisation in mankind living have augmented the textile and clothing industrial growth at a phenomenal rate, supported by technological advances in materials and operations[1]. Global fibre production is doubled in the last twenty years and reached to
107 million metric tons and will be reached to 145 million metric ton in 2030 [2]. Because of the increased clothing consumption, significant amount of waste is generated in pre-consumer and post-consumer usage. Increasing consumption has also created environmental issues such as decreased natural resources, reduced availability 
of freshwater, loss of arable land, exhaustion of finite energy resources and difficulty in disposal of waste. As a result, the textile industry has become the second most polluting industry after petrochemicals. Hence, it is essential to convert the waste textile and clothing materials into usable materials by using various concepts such as recycling, upcycling and zero waste. The recycling and reuse of textile materials is in vogue over many years in the textile and apparel industry. Recycling can be termed as the breakdown of product into its raw materials so as to reclaim the raw material for use in new products. In spite of considerable changes and development in waste management, average quantity of recycled textile waste is very low. Moreover, textile recycling is one of the oldest material recycling concept. According to the estimation, textile recycling stands at $15-20 \%$ now. But, steel, paper and plastics are recycled at $80 \%$, $65 \%$ and $30 \%$ respectively[3]. Since many years, a great amount of waste from post-consumer and post-industry have been disposing to landfills without any treatment. Recently, textile waste management has been changed by many countries and more awareness programs are conducted for the consumer[4],[5],6]. The information pertaining to health, safety and environment aspects of the textile articles to be informed to the consumer either directly through textile label or indirectly[7],[8]. Industries are also accelerated for modernisation and forced to carry out more projects aiming at waste reduction and landfill deposition. As a result, a good number of recycling technologies have been developed and less textile waste is disposed $[9,10]$.Hence, it is essential to intensify the textile recycling actions for achieving sustainable textile waste disposal. This study aims to investigate the factors influencing textile and clothing disposal behaviour by the consumer. In this study, the effect of factors, namely consumers knowledge on textile material care properties, Knowledge on recycling and reuse, environmental awareness on waste management attitude is studied.

This study has three hypotheses:

H1: Waste management attitude positively affect Knowledge on Textile \&Clothing Caring characteristics

H2: Waste management attitude positively affect Knowledge on Textile recycle

H3: Waste management attitude positively affect Knowledge on Environment concern

\section{LITERATURE REVIEW}

\section{A. Waste Management Attitude}

Textile and apparel manufacturing industry strives towards eco-friendliness and sustainability due to ecological requirement and social awareness. In the textile and garment industry, recycling and reusing of textile waste plays a significant role in sustainability. The utilization efficiency of textile recycling products has increased significantly. The willingness to recycle and donating the used clothing materials are considered as a disposal behaviour [11]. Clothing disposal behaviour is mainly influenced by environment awareness and recycling behaviour[12].Clothing material disposable behaviour is done by donation of used clothing to family members, friends and charities. Clothing re-use is done by many ways such as using of waste clothing materials for other purpose, selling, donating or giving it away [13].

\section{B. Knowledge On Textile \& Clothing Caring Characteristics}

Textile products purchase of a consumer is influenced by the consumers' attitude, product properties, care instructions and size. Apparel products purchase is positively influenced by the individuals attitude, environmental apparel knowledge and belief[14].Hence, the label is playing an important role in providing product properties and specification and thus resulting consumers' attitude and purchase decision $[15,16]$. The research on textile label is focusing on various aspects such as specification, consumer comprehension, social impacts, environmental impacts, economic impacts and health care [17]. The most understood care symbols were fibre, hand washing, do not wring, and ironing [18]. The importance of ethical, social and environmental issues of textile and clothing products are represented by the textile care labels [19]. Eco-labelling provides information related to environmental factors, production circumstances and employment process of textile articles [20].Textile recycling products are primarily produced based on the raw material derived from the old clothing and used products. The effectiveness of recycled product performance is greatly dependent upon the quality of the recycled yarn. Textile waste can be used to make products where virgin fibres are used. This will reduce energy consumption and other natural resources such as, air and water. Hence, the knowledge on 
used clothing materials are essential for the recycling process[21]. While combining fabrics, the similarity in parameters like weight, cleaning methods, shrinking behaviour in washing and ironing and accessories compatibility to be considered. Now a days, consumers are showing interest in learning the fibre content and maintenance requirement of the textile products. Though many varieties of fibres are used, the commonly used fibres, namely cotton, linen, wool, polyester, acrylic, acetate, and nylon in the textile and clothing industry [22].

Knowledge On Textile Recycle

Recycling is also referred to as exploiting material properties by transforming from one product to another. Recycling involves retrieving of the basic raw material from the used products and turning them into new products. Thus recycling process reduces the consumption of natural resources, energy consumption, the issue of waste disposal, and improves new product development[3].It is commonly practiced in textile and apparel product categories whereas the raw material is reclaimed in new products and retrofitting production chains [4]. Recycling raw material is retrieved from waste of pre-consumer and post-consumer products[6]. The recycling process is going to play a pivotal role in economic growth. PET bottles are converted into yarn and cloth for producing the products such as T- shirts, long underwear, sweaters, winter coats, athletic shoes, luggage bags, upholstery materials, fibre fill, sleeping bags, industrial strapping sheet, automotive parts and new PET containers [23]. Textile waste are converted into nonwoven materials that will be used for various industrial products. Nonwovens from recycled materials are used in automotive industry, sound absorption application [24-27]. Needle punching nonwoven technique is used to produce recycled nonwovens for the applications such as drainage, filtration, separation and soil protection [28]. All kinds of clothing materials can be used to make woven rugs, braided rugs and patch work-based products [21]. Eco-friendly consumption is largely influenced by positive fashion conscious of an customer [29].

\section{Knowledge On Environment Concern}

Environmental beliefs of an individual has a relation to environmental concern values or attitudes[30,31]. Environmental belief and knowledge is used as a predictor for environmental consumption behaviour[32]. According to market analysis, the majority of fibre consumption falls under the synthetic fibre category and a small percentage of consumption is in the natural fibre segment[9]. Polyester fibre consumption has increased drastically in the last decade and used in many areas account for more than $75 \%$ of the worldwide synthetic fibre production. It is resulted into accumulation of post-consumer waste in the environment [33]. So, it is essential to adopt eco-friendly process such as organic materials and recycling of waste $[34,35]$. Ecological problems are caused by the aggregation of non - biodegradable polymer waste [36-38]. Maximum synthetic fibres are belonging to the type of thermoplastic polymer in nature which is very much suitable for recycling [1]. Synthetic fibres have been produced from petroleum derived products and energy consumption is very high. Decomposition of petroleum based products is of major concern for ecology balance[6]. The disposed clothing made from polyester or lycra release methane, and 30-40 years are required to biodegrade[39]. By reducing the need of virgin fibres, landfill space and soil pollution also be reduced significantly. Due to the rapid growth towards polyester fibre consumption and polyester fibre production thereby, substantial energy is consumed by the industries amid the global energy crisis and associated menace to the environment $[9,10]$. Chemical recycling is mainly influenced by the nature of de-polymerization whereas mechanical recycling is standardized [40]. Because, PET is more easily recycled into useful products than other polymers [36-37]. These polymer materials are sorted based on color and types such as PET, HDPE, LDPE, etc. In addition to the waste produced by the consumer after the use, significant amount of waste is generated during the various textile manufacturing activities such as fibre scraps, yarn waste in spinning process and fabric waste in weaving, dyeing, printing, finishing process and scraps in clothing industry. Post-industrial waste is less diverse than post-consumer waste and later can be easily converted into similar or different products.

\section{METHODOLOGY}

This study examines the relationship between Textile and clothing disposal behaviour and knowledge factors of the consumer. Knowledge factors has been divided into three four categories with six statement for each factor, namely Knowledge on Textile \& Clothing Caring 
characteristics, Knowledge on Textile recycle and Knowledge on Environment concern. Knowledge on Textile \& Clothing Caring characteristics has been assessed with caring properties of cotton, linen, silk, wool, polyester and their degradation characteristics. Knowledge on Textile recycle is evaluated by the knowledge on existing recycle products, namely rugs, mats, bags, cushions, patch work products from cotton waste, recycled polyester and other used clothing materials. Knowledge on Environment concern is assessed by causes of environment pollution such as synthetic fibre usage, disposal of used apparel products, textile wet processing materials, organic fibre usage, environmental standard awareness. The independent variable, Textile and clothing disposable behaviour is measured through waste management attitude statements that identify consumers' willingness towards recycle textile waste, donate the used materials, reselling, throw away of used materials, reusing the waste materials for other purposes or recycling for the environment protection. A quantitative method with inferential statistics was used for understanding the waste management attitude on knowledge factors on Textile products, environment concern, and recycling. The data were collected through questionnaires distributed normally to a sample of 150 randomly selected customers through online. All statements in the questionnaire used a 5-point Likert scale $(1=$ Strongly disagree, $2=$ Disagree, $3=$ Neutral, $4=$ Agree, $5=$ Strongly agree)

\section{RESULTS}

The collected primary data is analysed by using SPSS Statistics for descriptive analysis, normality test and reliability. Correlation and regression analysis were carried out in order to obtain the relationship between variables. Kolmogorov Smirnov normal distribution test was carried out, and it was found that $\mathrm{p}$-value is more than 0.05 . So, Null Hypotheses was accepted. Therefore, a parametric test was used for the analysis. During the primary data collection, consumer demographic information was collected and analysed. The results are presented in Table 1.

It is observed from Table 1 that majority of the respondents $(31.3 \%)$ are in the age group of $31 \&$ 40 and least numbers $(18.0 \%)$ of respondents are above 50 years age group. The other age group such as below 30 and $41-50$ make $23.3 \%$ and $27.3 \%$ respectively. It is also revealed that majority of the respondents are male $(66.0 \%)$ and rest of them $(34.0 \%)$ are female. Based on marital status, $72 \%$ of respondents are married and $28 \%$ of them are unmarried. On educational Qualification, it is found that $42.0 \%$ of the respondents are post graduates, and a small number of respondents $(5.3 \%)$ are of Higher Secondary level. Also, 30.0\% customers are having Under Graduate education, and $22.7 \%$ have professional education.

Table -1: Descriptive analysis of respondents of demographic details

\begin{tabular}{|l|c|c|c|}
\hline $\begin{array}{l}\text { Demogra } \\
\text { phic } \\
\text { Variable }\end{array}$ & Classification & $\begin{array}{c}\text { No. of } \\
\text { respon } \\
\text { dents }\end{array}$ & Percentage \\
\hline Age & Below 30 & 35 & $23.3 \%$ \\
& $31-40$ & 47 & $31.3 \%$ \\
& $41-50$ & 41 & $27.3 \%$ \\
Gender & Above 50 & 27 & $18.0 \%$ \\
\hline Marital & Memale & 99 & $66.0 \%$ \\
Status & Married & 108 & $72.0 \%$ \\
\hline Educatio & Higher & 8 & $5.3 \%$ \\
$\mathrm{n}$ & secondary & & $30.0 \%$ \\
& Under & 45 & $42.0 \%$ \\
& Graduate & & $22.7 \%$ \\
& Post Graduate & 63 & \\
& Professional & & \\
& & 34 & \\
\hline
\end{tabular}

The case summary of the variables are presented in Table 2 and results show that waste management attitude meanvalue is higher than other categories and knowledge on environment concern is the lowest. The same trend is noticed in median and $75^{\text {th }}$ percentile values. The median value of knowledge on Environment concern is 18.00 . It shows that $50 \%$ of the respondents have expressed neutral option for the statements under Knowledge on environment concern, whereas in waste management attitude, the median value is 20 and contrast to the Knowledge on environment concern. Similarly, the median values for Knowledge on Textile \& Clothing caring and knowledge on textile recycle are same as 19.0.

Pearson correlation was used to find the correlation between the factors and summarized in Table 3. It is observed from that Waste management attitude is positively correlated with Knowledge on Textile \& Clothing Caring characteristics, Knowledge on Textile recycle and 
Knowledge on Environment concern with the correlation coefficient value of

$0.692,0.406$ and 0.303 respectively. The correlation coefficient between Knowledge on Textile \& Clothing Caring characteristics and Knowledge on Textile recycle is 0.447 which is the second highest value in the study. The lowest correlation is observed between Knowledge on Textile \&Clothing Caring characteristics and Knowledge on Environment concern with the value of 0.242 . The correlation coefficient values are significant at $95 \%$ confidence level.

Table -2: Case summary of variables

\begin{tabular}{|l|c|c|c|c|}
\hline & $\begin{array}{c}\text { Waste } \\
\text { mana } \\
\text { geme } \\
\text { nt } \\
\text { attitu } \\
\text { de }\end{array}$ & $\begin{array}{c}\text { Knowledg } \\
\text { e on T\&C } \\
\text { Caring }\end{array}$ & $\begin{array}{c}\text { Knowl } \\
\text { edge } \\
\text { on } \\
\text { Textile } \\
\text { recycle }\end{array}$ & $\begin{array}{c}\text { Knowled } \\
\text { ge on } \\
\text { Environ } \\
\text { ment } \\
\text { concern }\end{array}$ \\
\hline Mean & 19.92 & 19.10 & 18.80 & 17.89 \\
\hline $\begin{array}{l}\text { Median } \\
\left(50^{\text {th }}\right. \\
\text { Percentil } \\
\text { e) }\end{array}$ & 20.00 & 19.00 & 19.00 & 18.00 \\
\hline $\begin{array}{l}75^{\text {th }} \\
\text { Percentil } \\
\text { e }\end{array}$ & 23.25 & 22.00 & 20.80 & 20.00 \\
\hline
\end{tabular}

In this study, regression analysis was conducted for Knowledge on Textile \&Clothing Caring characteristics, Knowledge on Textile recycle and Knowledge on Environment concern and found below.

\section{A.Knowledge On Textile \&Clothing Caring Characteristics}

The table 4 provide the linear equation coefficient significance for the variables. It can be noticed that all significance figures ae $<0.001$. The regression equation from the table is

Knowledge on Textile \&Clothing Caring characteristics $=\mathbf{0 . 5 9 7}$ (Waste management attitude) +7.201

Here the coefficient of $\mathbf{X}$ is 0.597 represents the partial effect of Waste management attitude onKnowledge on Textile \&Clothing Caring characteristics. The estimated positive sign implies that such effect is positive that Knowledge on
Textile \&Clothing Caring characteristics would increase by 0.597 for every unit increase in waste management attitude and this coefficient value is significant at $1 \%$ level.

Table -4:Coefficients for the linear regression equation

\begin{tabular}{|c|c|c|c|c|c|}
\hline $\begin{array}{l}\text { Varia } \\
\text { bles }\end{array}$ & $\begin{array}{c}\text { Unstanda } \\
\text { rdized } \\
\text { co-efficien } \\
\mathrm{t}\end{array}$ & $\begin{array}{c}\mathrm{SE} \\
\text { of B } \\
\text { (B) }\end{array}$ & $\begin{array}{c}\text { Standar } \\
\text { dized } \\
\text { co-effici } \\
\text { ent } \\
\text { (Beta) }\end{array}$ & $\begin{array}{c}\mathrm{t} \\
\text { valu } \\
\mathrm{e}\end{array}$ & $\begin{array}{c}\mathrm{P} \\
\text { valu } \\
\mathrm{e}\end{array}$ \\
\hline $\begin{array}{c}\text { Const } \\
\text { ant }\end{array}$ & 7.201 & $\begin{array}{c}1.0 \\
48\end{array}$ & - & 6.8 & 0.0 \\
\hline $\mathrm{X}$ & 0.597 & $\begin{array}{c}0.0 \\
51\end{array}$ & 0.692 & $\begin{array}{c}11 . \\
646\end{array}$ & $\begin{array}{l}0.0 \\
00^{*}\end{array}$ \\
\hline
\end{tabular}

Note: * Denotes significant at $1 \%$ level

B. Knowledge on textile recycle

The table 5 provide the linear equation coefficient significance for the variables. It can be noticed that all significance figures ae $<0.001$. The regression equation from the table is

Knowledge on Textile recycle $\mathbf{=} \mathbf{0 . 3 5 8}$ (Waste management attitude) $+\mathbf{1 1 . 9 2 0}$

Table -5:Coefficients for the linear regression equation

\begin{tabular}{|l|c|c|c|c|c|}
\hline $\begin{array}{l}\text { Varia } \\
\text { bles }\end{array}$ & $\begin{array}{c}\text { Unstanda } \\
\text { rdized } \\
\text { co-efficien } \\
\mathrm{t} \\
\text { (B) }\end{array}$ & $\begin{array}{c}\text { SE } \\
\text { of B }\end{array}$ & $\begin{array}{c}\text { Standar } \\
\text { dized } \\
\text { co-effici } \\
\text { ent } \\
\text { (Beta) }\end{array}$ & $\begin{array}{c}\mathrm{t} \\
\text { valu } \\
\mathrm{e}\end{array}$ & $\begin{array}{c}\mathrm{P} \\
\text { valu } \\
\mathrm{e}\end{array}$ \\
\hline $\begin{array}{l}\text { Const } \\
\text { ant }\end{array}$ & 11.920 & 1.3 & & 8.8 & 0.0 \\
\hline $\mathrm{X}$ & 0.358 & 0.0 & 0.406 & 5.4 & 0.0 \\
& & 66 & & 07 & $00^{*}$ \\
\hline
\end{tabular}

Note: * Denotes significant at $1 \%$ level

Here the coefficient of $\mathbf{X}$ is 0.358 represents the partial effect of Waste management attitudeon Knowledge on Textile recycle. The estimated positive sign implies that such effect is positive that Knowledge on Textile recycle would increase by 0.358 for every unit increase in waste management attitude and this coefficient value is significant at $1 \%$ level.

C.Knowledge on environment concern

The table 6 provide the linear equation coefficient significance for the variables. It can 
be noticed that all significance figures ae $<0.001$. The regression equation from the table is

Knowledge on Environment concern $=\mathbf{0 . 2 8 4}$

(Waste management attitude) + $\mathbf{1 2 . 2 2 2}$

Here the coefficient of $\mathbf{X}$ is $\mathbf{0 . 2 8 4}$ represents the partial effect of Waste management attitude on Knowledge on Environment concern. The estimated positive sign implies that such effect is positive that Knowledge on Environment concern would increase by $\mathbf{0 . 2 8 4}$ for every unit increase in waste management attitude and this coefficient value is significant at $1 \%$ level.

Table -6: Coefficients for the linear regression equation

\begin{tabular}{|c|c|c|c|c|c|}
\hline $\begin{array}{l}\text { Varia } \\
\text { bles }\end{array}$ & $\begin{array}{c}\text { Unstanda } \\
\text { rdized } \\
\text { co-efficien } \\
\mathrm{t}\end{array}$ & $\begin{array}{c}\mathrm{SE} \\
\text { of B }\end{array}$ & $\begin{array}{c}\text { Standar } \\
\text { dized } \\
\text { co-effici } \\
\text { ent } \\
\text { (B) }\end{array}$ & $\begin{array}{c}\mathrm{t} \\
\text { valu } \\
\mathrm{e}\end{array}$ & $\begin{array}{c}\mathrm{P} \\
\text { valu } \\
\mathrm{e}\end{array}$ \\
\hline Const & 12.222 & 1.5 & - & 8.1 & 0.0 \\
ant & & 03 & & 29 & $00^{*}$ \\
\hline \multicolumn{1}{|c|}{$\mathrm{X}$} & 0.284 & 0.0 & 0.303 & 3.8 & 0.0 \\
& & 74 & & 64 & $00^{*}$ \\
\hline
\end{tabular}

Note: * Denotes significant at $1 \%$ level

\section{CONCLUSIONS}

The findings of the study reveals that customers are having higher waste management attitude than the knowledge factors. It shows that there is a lapse in knowledge factors. But the independent factor i.e. waste management attitude is positively correlated with Knowledge on Textile \& Clothing Caring characteristics, Knowledge on Textile recycle and Knowledge on Environment concern. It is observed from the above linear regression analysis that three hypotheses are supported. But, Knowledge on Textile and Clothing caring characteristics is having larger influence than other parameter on waste management attitude. It shows that respondents might be acquired the Textile and Clothing caring characteristics over the period of time though care instruction at the time of purchase, information through care label and usage experience. In contrast, the other knowledge parameters such as Knowledge on Textile recycle and Knowledge on Environment concern are not as much as familiar with Knowledge on Textile and Clothing caring characteristics. Though the waste management attitude is higher, it is essential to impart knowledge of the recycling and environment concern to the consumers in order to achieve sustainable waste management attitude. The study suggests the textile and clothing manufacturers should suggest the importance of environment concern and sustainable disposal ways through tags and awareness programs on recycle and ecological issues related to post-consumer waste in the retail outlet. As the collection of information is collected through online and limited number of respondents, the results cannot be generalised based on demographic profile which also gives the scope for future research. The studies can focus on influence on demographic variables and in the domain of comprehension of making instruction labels and their fixation, textile upcycling, recycling and reuse.

\section{ACKNOWLEDGEMENT}

The author is thankful to the students belong to semester -III of Textile Design Department, NIFT, Chennai for the part of the data collection.

\section{REFERENCES:}

[1]. Altun, S. (2016). Recycling, environmental and ecological effects of textile production and usage wastes. Usak: Chamber of Commerce and Industry Report.

[2]. https://textileexchange.org/wp-content/uploads/2019/1 1/Textile-Exchange_Preferred-Fiber-Material-Market-Repo rt_2019.pdf

[3]. Awaja, F., \& Pavel, D. (2005). Recycling of PET. European Polymer Journal, 41(7), 1453-1477.

[4]. Ismal, O. E., \&Y1ldırım, L. (2013). Environmentally friendly approaches in textile design. Mediterranean Art Journal, 5(8), 9-13.

[5]. Leonas, K. K. (2017). The use of recycled fibers in fashion and home products. In: S. S. Muthu (Ed.), Textiles and clothing sustainability, textile science and clothing technology. Singapore: Springer Science p Business Media. doi:10.1007/978-981-10-2146-6_2.

[6]. Mari, I., \& Shinji, Y. (2004). Performance and durability of woven fabrics including recycled polyester fibers. Journal of Textile Engineering, 50(2), 25-30.

[7]. Draxlerová M, Rusko $M$ and Kuracina M. Labelling Of Textile Products From The Perspective Of Quality, Maintenance, Safety And Environment. Research Papers Faculty of Materials Science and Technology Slovak University of Technology 2015; 57.

[8]. O'Flynn E. The world of textile labelling: Amsterdam University of applied sciences; 2015.

[9]. Park, S. H., \& Kim, S. H. (2014). Poly (ethylene terephthalate) recycling for high value added textiles. Fashion \& Textiles, 1(1), 1-17.

[10]. Payne, A. (2015). Open and closed-loop recycling of textile and apparel products. In Handbook of life cycle assessment (LCA) of textiles \& clothing,103-123. e-ISBN: 9780081001875 .

[11]. Bianchi, C., \& Birtwistle, G. (2010). Sell, Give Away, or Donate: An Exploratory Study of Fashion Clothing Disposal Behaviour in Two Countries. The International Review of 
Retail, Distribution and Consumer Research, 20(3), 353-368.

[12]. Morgan, L.R., \& G. Birtwistle. (2009). An Investigation of Young Fashion Consumer's Disposal Habits. International Journal of Consumer Studies 33, 190-198.

[13]. Aydin, H. (2017). Used Clothing Disposal Behavior within the Scope of Sustainable Consumption. International Journal of Academic Research in Economics and Management Sciences, 138-152.

[14]. Lang, C., \& Wei, B. (2019). Convert one outfit to more looks: factors influencing young female college consumers' intention to purchase transformable apparel. Fashion and Textiles, 6(1), 26.

[15]. Steyn L. Consumer perceptions regarding labels on clothing and household textile products: a study in Gauteng: North West University 2010.

[16]. Sanad RA. Consumer Attitude and Purchase Decision towards Textiles and Apparel Products. WJTET 2016; 2: 16-30.

[17]. Sanad, R. A. (2017). A Study of Issues Related to Labelling of Textile Articles. World, 3, 25.

[18].Calisir F, Gumussoy CA, Bozdurgut N, Topaloglu H and Bayraktaroglu $\mathrm{AE}$, editors. Comprehension of Care Label Symbols: Effects of Age, Gender, and Education Level. Proceedings of the World Congress on Engineering and Computer Science 2013; 23-25 October; San Francisco: Newswood Limited.

[19]. Erskine CC and Collins L. Eco-labelling: success or failure? Environmentalist 1997; 17(2): 125-33.

[20]. Kirsi L and Grimstad KI. Environmental and Ethical Perceptions Related to Clothing Labels Among Norwegian Consumers. RJTA 2013; 17(1): 50-8.

[21]. Koester, A. W. (1994). How to recycle clothing by restyling and making over.

[22]. Kalka, B. (1978). Labeling Hand Crafted Textile Items.

[23]. Uyanik, S. (2019). A study on the suitability of which yarn number to use for recycle polyester fiber. The Journal of The Textile Institute, 110(7), 1012-1031.

[24]. Kalebek, N. A. (2016). Sound absorbing polyester recycled nonwovens for the automotive industry. Fibres \& Textiles in Eastern Europe, 1(115), 107-113.

[25]. Del Sorbo, G., Truda, G., Bifulco, A., Passaro, J., Petrone, G., Vitolo, B., ... Branda, F. (2018). Non monotonous effects of noncovalently functionalized graphene addition on the structure and sound absorption properties of polyvinylpyrrolidone $(1300 \mathrm{kda})$ electro- spun mats. Materials, 12(1), 108.

[26].Na, Y., Agnhage, T., \& Cho, G. (2012). Sound absorption of multiple layers of nanofiber webs and the comparison of measuring methods for sound absorption coefficients. Fibers and Polymers, 13(10), 1348-1352.

[27]. Avcio!glu, N., Vuru skan, D., \&De!girmenci, Z. (2010, October). SesAbsorbsiyonundaKullanilmak U€ zereNanoliflerdenKaplamaMalzeme U€ retilmesi. Paper presented at the Smart Tetile Technologies R\&D Brokerage Event in Gaziantep, Turkey.

[28].Kopitar, D., Skenderi, Z., \&Rukavina, T. (2014). Impact of calendering process on nonwoven geotextiles hydraulic properties. Textile Research Journal, 84(1), 66-77.

[29]. Gam, H. J. (2011). Are fashion-conscious consumers more likely to adopt eco-friendly clothing? Journal of Fashion Marketing and Management, 15(2), 178-193.

[30]. Scott, D., \& Willits, F. K. (1994). Environmental attitudes and behavior. Environment and Behavior, 26(2), 239-260.

[31].Lee, Y.-K., Kim, S., Kim, M.-S., \& Choi, J.-G. (2014). Antecedents and interrelationships of three types of pro-environmental behavior. Journal of Business Research, 67(10), 2097-2105.

[32]. Corral-Verdugo, V., Bechtel, R. B., \&Fraijo-Sing, B. (2003). Environmental beliefs and water conservation: An empirical study. Journal of Environmental Psychology, 23(3), 247-257.

[33]. Smithers Pira Market Intelligence. (2012). The future of global PET packaging to 2017

[34].Shen, L., Worrell, E., \& Patel, M. K. (2010). Open-loop recycling: A LCA case study of PET bottle-to-fibre recycling. Resources, Conservation and Recycling, 55(1), 34-52.

[35]. Hustvedt, G., \& Dickson, M. A. (2009). Consumer likelihood of purchasing organic cotton apparel. Journal of Fashion Marketing and Management: An International Journal.

[36]. Gurudatt, K., De, P., Rakshit, A. K., \&Bardhan, M. K. (2003). Spinning fibers from poly (ethylene terephthalate) bottle-grade waste. Journal of Applied Polymer Science, 90(13), 3536-3545.

[37]. Shen, L., Worrell, E., \& Patel, M. K. (2010). Open-loop recycling: A LCA case study of PET bottle-to-fibre recycling. Resources, Conservation and Recycling, 55(1), 34-52.

[38]. Welle, F. (2011). Twenty years of PET bottle to bottle recycling-An overview. Resources, Conservation and Recycling, 55 (11), 865-875.

[39]. Olivia, (2019) retrieved from "http:// simplylivandco.com/blog/a-guide-to-textile-recycli ng" on 30.07.2020

[40].Venkatachalam, S., Nayak, S. G., Labde, J. V., Gharal, P. R., Rao, K., \& Kelkar, A. K. (2012). Degradation and recyclability of poly (ethylene terephthalate). In Saleh H.E.D.M. Saleh (Eds.), Polyester (pp. 75-98). InTech 